\title{
MEASURING CULTURE EFFECT SIZE DIFFERENCES IN SLOVENIAN AND PORTUGUESE LEADERSHIP PRACTICES: CROSS-CULTURAL LEADERSHIP UNIVERSALITY OR CONTIGENCY?
}

Matevž Rašković *

\section{Abstract}

This paper measures the cultural effect size across five types of leadership practices by using the Leadership Practice Inventory (LPI) instrument and drawing on the GLOBE research project framework. It tests cultural universality vs. contingency in five LPI leadership practices in an East-West EU comparison, both with an ex-socialist past. It employs four different effect size statistics. The paper contributes to the narrowing of the empirical gap in researching leadership practices in a small, East-West European country context. Only two of the five leadership practices show statistically significant effect sizes. Furthermore, the leadership practice Encouraging the heart is the only one to display a relatively moderate effect size. Thus, the evidence seems to support the universalist perspective over the contingency perspective.

Key words: leadership practices, LPI instrument, GLOBE project, culture effect size, Slovenia, Portugal

Acknowledgement: I would like to acknowledge the contribution of Špela Kržišnik, who collected the data as part of her master's thesis at the Faculty of Economics, University of Ljubljana.

JEL classification: M00, M120, Z100

\section{INTRODUCTION}

The emergence of cross-cultural leadership builds on the Implicit Leadership Theory (ILT) (Lord and Maher 1990), and the evolution of the so-called Culturally-Endorsed Implicit Leadership Theory (CLT) (Bullough and Sully de Luque, 2014; House et al. 2004). Furthermore, issues of cross-cultural leadership, and the questions of universality vs. cultural contingency of leadership practices, are often associated with the so-called contextualist perspective in the leadership literature (Dickson et al., 2012; Javidan et al., 2010; Avolio 2007). Despite the fact that cross-cultural leadership research has gained momentum since the 1990s, House, Wright and Aditya (1997) have pointed to a plethora of theoretical, methodological, and empirical questions still to be addressed. Similarly, Avolio (2007) also pointed to research on specific leadership practices, where questions regarding universality vs. the cultural contingency of leadership practices still need more research, particularly in small, East-West cultural comparisons (e.g. Steyrer, Hartz and Schiffinger 2006). The importance of cross-cultural universality vs. contingency of leadership has been more recently revisited within a special issue of the Journal of World Business focusing on the link between national culture, leadership and organizational behavior, and which has re-established the question of the relationship between culture and leadership as a central future research direction (Steers, Sanchez-Runde and Nardon, 2012; Dickson et al., 2012). This call has also gained new momentum in the face of the aftermath of the 2008 global and economic crisis, which has caused leadership scholars to reexamine traditional leadership theory (Mabey and Morrell, 2011). This research explores the relationship between national culture, and the use of particular leadership practices. It is based on the GLOBE methodology framework, which has recently celebrated its twentieth research anniversary as the premier research platform for cross-cultural leadership research (Dorfman et al., 2012), and the self-reported

\section{* Matevž Rašković, PhD}

Assistant professor of international business University of Ljubljana, Faculty of Economics E-mail: matevz.raskovic@ef.uni-lj.si 
version of the Leadership Practice Inventory (LPI) developed by Kouzes and Posner (1993). The main purpose of this paper is to outline the applicability of power analysis and to employ four different types of effect size measures in order to measure culture effect size differences across five leadership practices in Slovenia and Portugal within the GLOBE methodology.

An important empirical contribution of the research lies in its East-West, small country cultural comparison, where particular attention is paid in the research to why comparing Slovenian and Portugal is valid. In this regard, it must be noted that the bulk of traditional leadership theories, and the various types of leadership practice typologies developed, have been based on large, highly individualistic western national cultures (Steers, Sanchez-Runde and Nardon, 2012; Kabasakal et al., 2012; Hofstede 1993, House 1995, Mellahi 2000). Thus, the bulk of contemporary traditional leadership theories offer few, if any, possibilities for assessing cross-cultural validity across the globe. This is a concern, particularly because the concept of leadership seems to be culturally embedded through the social construction of not only value, but also expectations (Dorfman et al., 2012).

In this regard, Grachev and Bobina (2006) emphasize the specific value of small and Eastern cultural contexts with a socialist history. Conducting cross-cultural leadership practice research in these contexts is valuable, because such cultures are usually characterized by high degrees of power distance, and low degrees of individualism (Ergeneli, Gohar and Temirbekova 2007). According to evidence from international management projects provided by Low and Shi (2001) these two dimensions, and in particular power distance, have been most strongly associated with managing employees and engaging their motivation.

\section{POWER ANALYSIS AND ITS APPLICABILITY IN MANAGEMENT RESEARCH}

Cohen (1988, pp. 9-10) defines effect size as "the degree to which the phenomenon is present in the population or the degree to which the null hypothesis is false". Due to the underlying complexity of most psychological and social phenomena Van de Vijver (2003) points out that statistics should in these contexts look beyond testing merely for statistical differences. Cankar and Bajec (2003) believe the use of significance testing to be actually more harmful than beneficial to scientific research, since it is not complemented by an evaluation of sizes (Thomson 1999), and is influenced by sample size (Breaugh 2003).

Despite the substantive value of measuring effect size Cohen (1992, p. 155) noted that even with psychological research most "researchers continue to ignore power analysis" leading to a "low level of consciousness about effect size". While more recently this trend has started to improve, it has been employed in a too "simplistic manner" (Breaugh 2003, p. 79).

Given a careful overview of the literature and various effect size measures, as well as based on the recommendations by Breaugh (2003) four different effect size measures are employed in the research as summarized in Table 1.

Table 1: Effect size measures and their methodological background

\begin{tabular}{|c|c|c|c|}
\hline Measure & Type & Formula & Reference values \\
\hline $\begin{array}{l}\text { Partial eta squared } \\
\qquad\left(\eta_{p}^{2}\right)\end{array}$ & Explained variance & $\eta_{p}^{2}=\frac{S S_{\text {effect }}}{S S_{\text {effect }}+S S_{\text {error }}}$ & $\begin{array}{c}\text { Young (1993): effect size as a } \\
\text { percentage }\end{array}$ \\
\hline Cohen's $d$ & Std. mean difference & $\begin{array}{c}d=\left(M_{1}-M_{2}\right) / \sigma_{\text {pooled }} \\
\sigma_{\text {pooled }}=\sqrt{\frac{1}{2}\left(\sigma_{1}+\sigma_{2}\right)}\end{array}$ & $\begin{array}{l}\text { Cohen (1988): } \\
\text { small: } 0.2, \text { medium: } 0.5 \\
\text { and large: } 0.8\end{array}$ \\
\hline $\begin{array}{l}\text { Omega squared } \\
\qquad\left(\omega^{2}\right)\end{array}$ & Explained variance & $\omega^{2}=\frac{\left(S S_{\text {treatmen } t}-(k-1) * M S_{\text {error }}\right.}{\left(S S_{\text {total }}+M S_{\text {error }}\right)}$ & $\begin{array}{l}\text { Cohen (1988): small: 0.01, } \\
\text { medium: } 0.06 \text { and large: } 0.14\end{array}$ \\
\hline $\begin{array}{l}\text { Common language } \\
\text { effect size }(C L)\end{array}$ & $\begin{array}{c}\text { Effect size converted into } \\
\text { probability(based on mean } \\
\text { difference) }\end{array}$ & $\begin{array}{l}\text { Z score translated to a probability } \\
\text { distribution: } \\
\qquad \mathrm{Z}_{\mathrm{CL}}=\frac{M_{1}-M_{2}}{\sqrt{V a r_{1}+\operatorname{Var}_{2}}}\end{array}$ & See McGraw and Wong (1992) \\
\hline
\end{tabular}

Note: $S S_{\text {effect }}=$ sum of squares for effect of interest; $S S_{\text {error }}=$ sum of squares for error term; $\sigma=$ standard deviation; $\sigma^{2}=$ variance; $S S$ $=$ sum of squares between groups; $S S_{\text {total }}=$ total sum of squares; $M S_{\text {error }}=$ mean square of the error term 


\section{THE LPI INSTRUMENT}

Addressing particular leadership practices associated with the six outlined leadership types the GLOBE research project measures five key neo-charismatic leadership practices outlined by Kouzes and Posner's (1987) LPI instrument, shown in Table 2.

The LPI instrument has time and again shown its "psychometric soundness" (Huber et al. 2000, p. 251), and produced consistent validity and reliability statistics (Kouzes and Posner 2001). It has further importantly proven its leadership practices to be unrelated to either various respondents' demographic or organizational characteristics.

Particularly important to cross-cultural leadership research, the LPI instrument has been employed in a series of cross-cultural comparisons. Backed by over 20 years of research and application, this paper employs the LPI instrument both because it is "one of the most well-developed and used instruments for examining leadership behavior" (Chen and Baron 2007, 8), and in particular its proven usefulness in cross-cultural leadership comparisons (Tang, Yin and Nelson 2010.).

\section{COMPARING SLOVENIA AND PORTUGAL}

The comparison of Slovenia and Portugal is based on the fact that both countries are small European countries, with important geo-strategic positions (Udovič and Svetličič 2012). Both are important trading hubs in the region. Both are also very much export-oriented, with most of their exports linked to the EU market and other neighboring nonEU countries. They also share a recent history of socialist rule, ending in Slovenia in 1991 and in 1974 in Portugal. Portugal became member of the EU in 1986, Slovenia in 2004. They are quite similar with regard to average EU-28 GDP per capita and have been similarly hard hit in the aftermath of the 2008 global economic and financial crisis. These characteristics provide a match on several important country socio-economic indicators, as pointed out by Häder and Gabler (2003). Furthermore, Slovenia's cultural similarity to other Western Balkan countries may mean that the results of such comparisons can be used as a "yard stick" for the wider region of the Western Balkans (Udovič 2011; Zupančič and Udovič 2011).

Table 2: Leadership practices within Kouzes and Posner's LPI instrument

\begin{tabular}{|c|c|}
\hline Leadership practice & Short description \\
\hline $\begin{array}{l}\text { Challenging the process } \\
\qquad(\mathrm{CP})\end{array}$ & $\begin{array}{l}\text { Searching for opportunities to change status quo. Looking for innovative ways of } \\
\text { organizational improvement. Experimentation and risk taking, accepting possible } \\
\text { disappointment as learning. }\end{array}$ \\
\hline $\begin{array}{l}\text { Inspiring a shared vision } \\
\text { (ISV) }\end{array}$ & $\begin{array}{c}\text { A passionate belief for making a difference. Envisioning the future, creating a unique } \\
\text { image of what an organization can become. Enlisting employees in leader's vision } \\
\text { through magnetism and persuasion. }\end{array}$ \\
\hline $\begin{array}{l}\text { Enabling others to act } \\
\qquad \text { (EOA) }\end{array}$ & $\begin{array}{l}\text { Fostering collaboration and team spirit. Active involvement of others. } \\
\text { Creating a atmosphere of trust and dignity. }\end{array}$ \\
\hline $\begin{array}{l}\text { Modeling the way } \\
\qquad(\mathrm{MW})\end{array}$ & $\begin{array}{l}\text { Creating standards of excellence and setting examples to follow. } \\
\text { Creating a context of small wins to achieve large objectives. }\end{array}$ \\
\hline $\begin{array}{l}\text { Encouraging the heart } \\
\qquad(\mathrm{EH})\end{array}$ & $\begin{array}{c}\text { Recognizing individual contributions. Celebrating accomplishments. } \\
\text { Making people feel like heroes. }\end{array}$ \\
\hline
\end{tabular}

Source: Kouzes and Posner, 2001, p. 4.

Table 3: Comparison of the Slovenian and Portuguese culture based on GLOBE typology

\begin{tabular}{|c|c|c|c|c|c|}
\hline & & \multicolumn{2}{|c|}{ SLOVENIA } & \multicolumn{2}{|c|}{ PORTUGAL } \\
\hline & & Practice & Value & Practice & Value \\
\hline \multirow{9}{*}{$\begin{array}{c}\text { GLOBE } \\
\text { project }\end{array}$} & Performance orientation & 26 & 90 & 23 & 89 \\
\hline & Future orientation & 32 & 58 & 38 & 59 \\
\hline & Egalitarianism & 92 & 83 & 73 & 98 \\
\hline & Assertiveness & 41 & 67 & 18 & 32 \\
\hline & Institutional collectivism & 45 & 30 & 34 & 81 \\
\hline & In-group collectivism & 67 & 49 & 70 & 63 \\
\hline & Power distance & 75 & 33 & 81 & 21 \\
\hline & Human orientation & 30 & 48 & 36 & 51 \\
\hline & Uncertainty avoidance & 36 & 75 & 41 & 52 \\
\hline
\end{tabular}

Source: House et al. (2004). Note: Hofstede scale between 0 and 120; GLOBE scores on a scale between 0 and 100. 
In addition, the national cultures of Slovenia and Portugal share some similarities, mainly in terms of high power distance, low degrees of individualism and masculinity, and high uncertainty avoidance. Table 3 displays a comparison of the Slovenian and Portuguese cultures within the GLOBE (2004) cultural typologies.

According to empirical evidence from managing international projects, power distance "seems to have the greatest influence" while uncertaincy avoidance "seems to have little or no influence" on international managerial contexts (Low and Shi 2001, p. 284). These findings can be extended to testing cross-cultural differences in leadership practices and the estimation of culture effect sizes across different cultural contexts. Given the high degree of similarity of Slovenia and Portugal in terms of their power distance, uncertainty avoidance and individualism within the GLOBE cultural comparison (as well as Hofstede's typology), one would thus expect no significant score differences in leadership practices between the two countries.

Furthermore, the empirical evidence presented by Zagoršek, Jaklič and Stough (2004) has in general shown only very limited support for the cultural contingency of leadership practices, even in very different cultural settings. This may in turn indicate a higher degree of cultural universality of transformational leadership practices (Ergeneli, Gohar and Temirbekova 2007). Thus, one would expect nonsignificant culture effect sizes between the two countries.

\section{SAMPLING AND MEASUREMENT}

\subsection{Sample}

The sample included 211 working (part-time) MBA students from Slovenia and Portugal. The data was collected in 2007 through a standardized self-reported version of the LPI instrument (Kouzes and Posner 1987), administered in a local language. Thus, the data represents a pre-crisis leadership practices comparison between Slovenia and Portugal. Values tend to be fairly stable over the short run and change only across generations. On the other hand, "normal" practices and behavior may become significantly distorted in a time of crisis (Mabey and Morrell, 2011); thus the pre-crisis data actually offers a more realistic insight into the leadership practices of the two countries. While the samples may not be large in terms of size, they are based on the very small MBA populations in both countries.

The sample data was collected based on a matched sample approach (Van de Vijver and Leung 1997), where respondents were matched according to level of education, as well as displaying similar age and gender structures. The use of matched sampling, with corresponding control variables (age, gender, work experience, etc.) has been outlined as valid in cross-cultural research by Cavusgil and Das (1997), and Schwartz and Sagie (2000). Furthermore, all respondents were offered a report on the obtained results in order to increase respondent involvement, which in turn increases survey participation (Kolar 2008).

While Bello et al. (2009) point to the 'scrutinized validity' of student samples in cross-cultural comparisons most of these critiques are directed towards undergraduate student samples. According to Bello et al. (2009, p. 363) MBA student samples may be "justifiable, because they typically have some working experiences". They continue by saying that "typically part-time [working MBA] students, should not pose a significant threat to external validity". Additionally, the cross-country comparison in Central and Eastern Europe (CEE) by Čater, Lang and Szabo (2013) within the so called GLOBE Students project - a direct extension from the original GLOBE project - has also shown students to be good proxies of future leaders in terms of their values and leadership expectations. A similar conclusion was also made by Mihelič and Lipičnik (2010) in a comparison of manager vs. student values in Slovenia. In their research, values have been established not only as a good predictor of peoples' behavior (Ferić 2007), but as good predictors of economic outcomes (Potočan, Mulej and Čančer 2008). Table 4 provides a more detailed summary of the key sample characteristics. Most of the respondents (74\%) work in a middle-sized or large privately owned company.

In terms of work experience, $37.2 \%$ had work experience in finance and accounting, $24.6 \%$ in sales and marketing, and $13.6 \%$ in IT. As we can see from Table 3, over a quarter of Slovene respondents and a third of Portuguese respondents already occupied some sort of managerial-level position, either bottom or middle-level positions.

Table 4: Sample characteristics $(n=211)$

\begin{tabular}{|c|c|c|}
\hline & Slovenia & Portugal \\
\hline Number of respondents & 115 & 96 \\
\hline Share of female / male respondents & F: $50.4 \% ;$ M:49.6\% & F: $49 \% ;$ M: $51 \%$ \\
\hline Average respondent age & 28.9 years & 31.9 years \\
\hline Share of respondents up to 30 years old & $73.9 \%$ & $48.9 \%$ \\
\hline Average work experience & 4.46 years & 10.03 years \\
\hline Share of respondents in bottom or middle management & $27.7 \%$ & $37 \%$ \\
\hline
\end{tabular}




\subsection{The LPI instruments reliability}

In 1993 the LPI instrument was cross-validated in an extensive sample of over 36,000 managers across various company management development programs, similar to MBAs (Kouzes and Posner 1993). The testing proved the "sound psychometric properties" of the instrument (Zagoršek 2004, p. 134), good construct and concurrent validity and internal reliability (Kouzes and Posner 1993.).

Within the Slovenian and Portuguese sample the overall reliability of the LPI survey instrument was 0.86 , as measured by the Cronbach alpha. While all five practices satisfied the 0.60 Cronbach alpha criteria, as proposed by Hair et al. (1998), the value was borderline for the practice Enabling others to act. Because of this, the reliability of the LPI instrument was also alternatively tested as a measurement model within a structural equation model (Bollen 1989), using the statistical software package Mplus. It produced the following goodness-of-fit statistics: $X^{2} / d f=3.13, p=0.000, R M S E A=0.054$, $C F I=0.94, T L I=0.91$.

\section{RESULTS}

\subsection{Impact of demographic variables on leadership behaviors and practices}

One of the key advantages of the LPI instrument is that leadership practice scores obtained with it have consistently been shown to be unrelated to demographic characteristics, such as age, gender, years of work experience, and even educational level (Kouzes and Posner 2001).

Table 5 reports the results of a one-way ANOVA testing for differences across all five leadership practices composite scores due to gender, age, and years of work experience. Despite differences in the average number of years of work experience in the Slovene and Portuguese samples, no statistical differences in the scores across all five leadership practices have been detected within one-way ANOVA. The same holds also for gender and age of respondents.

Next, Table 6 displays the average composite scores and their standard deviations for all five leadership practices individually, as well as jointly for the whole LPI instrument. It is also complemented by the level of statistically significant differences within ANOVA.

As we can observe from the corresponding scores, two out of five leadership practices are statistically significant between Slovenia and Portugal. Thus, based on the sample data, the Portuguese respondents on average displayed statistically significantly higher scores for the leadership practice Modeling the way, while the Slovene respondents on average displayed statistically significantly higher scores for the leadership practice Encouraging the heart. In both samples the highest average cumulative scores pertained to the leadership practice Enabling others to act, and the lowest for Inspiring a shared vision.

Table 5: Testing for differences in leadership practices based on demographics

\begin{tabular}{|c|c|c|c|c|c|c|c|c|c|c|}
\hline & \multicolumn{2}{|c|}{ MW } & \multicolumn{2}{|c|}{ ISV } & \multicolumn{2}{|c|}{$\mathrm{CP}$} & \multicolumn{2}{|c|}{ EOA } & \multicolumn{2}{|c|}{$\mathrm{EH}$} \\
\hline & $F$ & $p$ & $F$ & $p$ & $F$ & $p$ & $F$ & $p$ & $F$ & $p$ \\
\hline Gender & 1.6 & 0.211 & 0.05 & 0.831 & 0.4 & 0.529 & 0.3 & 0.575 & 0.2 & 0.649 \\
\hline Age & 1.5 & 0.195 & 1.57 & 0.170 & 0.3 & 0.934 & 0.7 & 0.647 & 0.4 & 0.834 \\
\hline Years of work experience & 1.5 & 0.199 & 1.75 & 0.124 & 0.4 & 0.884 & 0.4 & 0.856 & 1.64 & 0.151 \\
\hline
\end{tabular}

Note: $F=F$-test value; $p=$ level of statistical significance; $C P=$ Challenging the process; ISV=Inspiring a shared vision; $E O A=E n a b l i n g$ others to act; $\mathrm{MW}=$ Modeling the way; $\mathrm{EH}=$ Encouraging the heart.

Table 6: A comparison of leadership practice scores for Slovenia and Portugal

\begin{tabular}{|c|c|c|c|c|c|c|}
\hline & \multicolumn{2}{|c|}{ Slovenia } & \multicolumn{2}{|c|}{ Portugal } & \multirow{2}{*}{ F value } & \multirow{2}{*}{$p$} \\
\hline & Mean & SD & Mean & SD & & \\
\hline Modeling the way (MW) & 42.4 & 6.6 & 44.8 & 6.7 & 7.1 & $0.008^{*}$ \\
\hline Inspiring a shared vision (ISV) & 39.1 & 7.3 & 40.8 & 9.3 & 2.2 & 0.140 \\
\hline Challenging the process $(\mathrm{CP})$ & 44.4 & 6.5 & 44.1 & 7.2 & 0.8 & 0.775 \\
\hline Enabling others to act (EOA) & 48.1 & 5.2 & 47.6 & 5.9 & 0.4 & 0.531 \\
\hline Encouraging the heart $(\mathrm{EH})$ & 47.9 & 6.2 & 44.9 & 6.3 & 12.2 & $0.001^{*}$ \\
\hline Total LPI & 44.4 & 5.0 & 44.4 & 6.0 & Not $a$ & cable \\
\hline
\end{tabular}

Note: $\mathrm{SD}=$ standard deviation; * statistically significant. 
Table 7: Effect size statistics for a Slovenian-Portuguese leadership practice comparison

\begin{tabular}{|c|c|c|c|c|c|c|c|}
\hline & \multicolumn{2}{|c|}{$\eta_{p}^{2}$} & \multirow{2}{*}{$\begin{array}{c}\omega_{\mathrm{p}}{ }^{2} \\
\text { Value }\end{array}$} & \multirow{2}{*}{$|d|$} & \multicolumn{2}{|c|}{$C L$} & \multirow{2}{*}{ Overall effect size } \\
\hline & Value & $p$ & & & Value & $\%$ & \\
\hline Modeling the way (MW) & 0.033 & $0.008^{*}$ & 0.028 & 0.367 & 0.579 & $57.9 \%$ & Negligible \\
\hline Inspiring a shared vision (ISV) & 0.010 & 0.140 & 0.006 & 0.202 & 0.540 & $54.0 \%$ & Negligible \\
\hline Challenging the process $(C P)$ & 0.000 & 0.775 & -0.004 & -0.041 & 0.500 & $50.0 \%$ & Negligible \\
\hline Enabling others to act (EOA) & 0.002 & 0.531 & -0.002 & -0.087 & 0.500 & $50.0 \%$ & Negligible \\
\hline Encouraging the heart $(\mathrm{EH})$ & 0.055 & $0.001^{*}$ & $0.051^{* *}$ & $0.484^{* *}$ & 0.618 & $61.8 \%$ & Small to moderate \\
\hline
\end{tabular}

Note: $|d|$ refers to an absolute Cohen's $d$ statistic value. ${ }^{*}$ Statistically significant at $p<0.05 .{ }^{* *}$ Moderate effect size according to Cohen (1988).

\subsection{Culture effect sizes}

Based on the measures of effect size described above and the argument for their use Table 7 displays a summary of the effect size results across all four effect size statistics used. While the partial eta squared $\left(\eta_{p}^{2}\right)$ measure of effect size shows two significant effect sizes for leadership practices Modeling the way (3.3\% effect size) and Encouraging the heart (5.5\% effect size), both omega squared $\left(\omega^{2}\right)$ and Cohen's $d$ statistics show the leadership practice Encouraging the heart to be the only one with a moderate effect size. This is complemented by the fact that picking any of the respondents from the Slovenian sample will result in a $61.8 \%$ probability of displaying a higher score of the Encouraging the heart leadership practice compared to the Portuguese sample.

Having said this, I conclude that the leadership practice dimension of Encouraging the heart to be the only one out of the five LPI leadership practice dimensions to display relatively moderate effect size differences between the Slovenian and Portuguese respondents. This finding may have important theoretical implications - of course pending broader cross-validation - which may signal a need to return to the earlier universalist perspective on leadership, since most of the current research on cross-cultural leadership has advocated a pure contingency perspective or a domination of contingency over universality (Moan and Hetland, 2012).

\section{LIMITATIONS OF THE RESEARCH}

MBA students are still proxies for real managers and leadership behavior. They are themselves subject to strong self-selection criteria and display certain common personal characteristics, and are subject to fairly universal western education on effective leadership behavior and practices (Blunt and Jones 1997). We see this fact, and the fact that our data was collected in 2007, as the biggest limitations of the research. Nevertheless we have already acknowledged that the pre-crisis data may provide more realistic insight into leadership practices.

The second set of limitations may be applied to the LPI instrument itself. As with all complex social and psychological phenomena, it is impacted by a complexity of causal and interrelated variables and antecedents, which in turn call for multi-level measurement and analytical approaches (Yammarino et al. 2005). The LPI instrument or any other typology based instrument may not capture the complexity of such behavior. The LPI instrument has in turn also been criticized for being groundbreaking two decades ago, but not anymore. According to Scherbaum et al. (2006) classical psychometric techniques should be complemented by more recent psychometric advances, such as, for example, item response theory and models. While these issues may be valid, the LPI instrument in its current form is today still one of the two most extensively used and empirically validated measurement instruments in the study of leadership.

The analyses have aimed to address the issue of culture effect size across different leadership practices, given the concerns raised about classical significance testing (Breaugh 2003). While I have employed several different effect size measures to provide more robust solutions, Yammarino et al. (2005) and Javidan et al. (2010) still point to a lack of multi-level analyses in research of leadership phenomena, which is also valid here.

Lastly, it also needs to be acknowledged that while Slovenia and Portugal were chosen as two small states in a West-East European comparison, they do have completely different languages (bearing in mind that language is a cultural vehicle (Hofstede, 1986)) have different historical embeddedness (particularly Portugal's strong political power in the middle ages) and different neighboring influences (Slovenia has four EU neighbors; Portugal has only one).

\section{DISCUSSION OF LEADERSHIP PRACTICE SCORES}

First, while not disregarding the concerns raised over both Hofstede's methodology (Schwartz 1999, McSweeney, 2002) and the methodology of the GLOBE project (Hofstede 2006), I believe that, based on the work of Low and Shi (2001) the large degree of universality between the two countries can be explained by the level of similarity between Slovenia and Portugal in terms of power distance. This in turn indicates that the cross-cultural validity of leadership theories may hold across East-West contexts with comparable cultural backgrounds. 
Table 8: A comparison of the Slovenian and Portuguese national character dimensions

\begin{tabular}{|l|c|c|c|c|c|}
\hline & Neuroticism & Extraversion & Openness & Agreeableness & Conscientiousness \\
\hline Slovenia & 54.7 & 41.4 & 44.2 & 46.9 & 55.6 \\
\hline Portugal & 47.5 & 56.7 & 55.1 & 53.0 & 48.2 \\
\hline
\end{tabular}

Source: National Character Survey, Terraciano et al. 2005.

Second, I believe the degree of cultural contingency with regard to the leadership practice dimension of Encouraging the heart can be explained by looking at both the individualism and masculinity contexts in the two countries, as well as at the differences in their national characters. With regard to the former, Low and Shi (2001) have shown both individualism and masculinity dimensions to be linked to employee motivation in international projects. With regard to the latter, the evidence from the National Character Survey (Terracciano et al. 2005) helps us better understand the 'psychological profiles' of their national characters, from which a greater need for mobilizing emotions in leadership for Slovenia also emerges. Having said this, Table 8 provides a brief comparison of Slovenia and Portugal within the five psychological dimensions of their national characters.

I believe that in a highly egalitarian cultural setting, Slovenians need to practice institutional and in-group collectivistic behavior much more than they actually value it, resulting in high levels of importance for trust (Kovač and Jesenko 2010). This is not the case in Portugal, where institutional behavior is actually considerably more valued than practiced, and where the practice and valuation of in-group collectivistic behavior is more closely aligned. While both countries score very low on masculine values, the level of practiced and valued assertive behavior is considerably higher in Slovenia than in Portugal. I believe this indicates a much stronger existence of "self" in Slovenia vis-à-vis Portugal. This self has however a stronger propensity towards neuroticism associated with higher levels of anxiety, hostility and depression (Terraciano et al. 2005). It is constrained by higher degrees of introversion and much more limited openness compared to the Portuguese national character. It is split between a high propensity towards conscientiousness and doing the "right thing", while at the same time being less agreeable, trusting and compliant per se compared to the Portuguese.
In such a setting the Slovene worker does not tend to stand out, is hidden by the collective, always does the "right thing", and does not like change (Mühlbacher, Nettekoven and Kovač 2011). In turn, he or she looks for emotional validation and recognition as an individual, and displays a strong tendency towards transformational leadership (Zagoršek, Dimovski and Škerlavaj 2009), leading to a significantly higher importance for Encouraging the heart. Such leadership behavior not only fuels conscientiousness and motivates the worker, but also compensates his ambivalence between assertive behavior and standing out from the collective, at the same time alleviating neurotic elements of his or her national character. Furthermore, the results for the importance of the leadership practice Encouraging the heart for Slovenia, vis-à-vis Portugal, seem also to be consistent with the results obtained by Ergeneli, Gohar and Temirbekova (2007), which show higher power distance and higher level of collectivism to be closely related to this leadership practice. Furthermore, according to Šverko (2009), higher levels of collectivism are also associated with a higher importance for emotions in human behavior; which can be closely related to the importance of the leadership practice Encouraging the heart.

This research has aimed to show the applicability of power analysis and various effect size statistics in cross-cultural management research, as well as to provide a brief discussion of the obtained results. In terms of the results, they indicate that a large degree of leadership universality can be attributed to the cultural similarity of the compared countries, where power distance seems to be a key cultural dimension with regard to the universality of leadership practices. This has important implications for leadership practice, where special attention should be paid to this cultural dimension. The results of the employed research also support towards a cross-cultural validation of the LPI instrument in an EastWest Slovenian-Portuguese comparison. 


\section{REFERENCES}

Avolio, B. J. 2007. Promoting more integrative strategies for leadership theory building. American Psychologist 62 (1): 25-33.

Bello, D., Leung, K., Radebaugh, L., Tung, R.L. and van Witteloostujin, A. 2009. From the Editors: Student samples in international business research. Journal of International Business Studies 40 (4): 361-364.

Blunt, P. and Jones, M.L. 1997. Exploring the Limits of Western Leadership Theory in Asia and Africa. Personnel Review 26 (1/2): 6-24.

Bollen, K. A. 1989. Structural equations with latent variables. New York: Wiley.

Breaugh, J. A. 2003. Effect Size Estimation: Factors to consider and mistakes to avoid. Journal of Management 29 (1): 79-97.

Bullough, A. and Sully de Luque, M. 2014. Women's participation in entrepreneurial and political leadership:The importance of culturally endorsed implicit leadership theories. Leadership (early cite online publication) DOI: 10.1177/1742715013504427.

Cankar, G. and Bajec, B. 2003. Velikost učnika kot dopolnilo testiranju statistične pomembnosti razlik. Psihološka Obzorja / Horizons of Psychology 12: 97-112.

Cavusgil, S. T. and Das, A. 1997. Methodological issues in empirical cross-cultural research: A survey of the management literature and a framework. Management International Review 37 (1): 71- 96.

Chen, H.-C. and Baron, M. 2007. Psychometric Properties of the Chinese Leadership Practice Inventory. International Journal of Nursing Education Scholarship 4 (1): 1-16.

Cohen, J. 1988. Statistical power and analysis for the behavioral sciences. Hillsdale, NJ: Erlbaum.

Cohen, J. 1992. A power primer. Psychological Bulletin 112 (1): 155-159.7

Čater, T., Lang, R. and Szabo, E. 2013. Values and leadership expectations of future managers: Theoretical basis and methodological approach of the GLOBE Student project. Journal for East European Management Studies 18 (4): 442-462.

Dickson, M. W., Castano, N., Magomaeva, A. and Den Hartog, D. N. 2012. Conceptualizing leadership across cultures. Journal of World Business 47 (4): 483-492.

Dorfman, P., Javidan, M., Hanges, P., Dastmalchian, A. and House, R. 2012. GLOBE: A twenty year journey into the intriguing world of culture and leadership. Journal of World Business 47 (4): 504-518.

Ergeneli, A., Gohar, R. and Temirbekova, Z. 2007. Transformational leadership: Its relationship to culture value dimensions. International Journal of Intercultural Relations 31 (4): 703-724.

Ferić, I. 2007. Univerzalnost sadržaja i structure vrijednosti: podaci iz Hrvatske. Društvena istraživanja 16 (1-2): 3-26.

Grachev, M. V. and Bobina, M.A. 2006. Russian Organizational Leadership: Lesson from the Globe Study. International Journal of Leadership Studies 1 (1): 67-79.

Hair, J. F., Anderson, R., Tatham, R. L. and Black, W. C. 1998. Multivariate data analysis. Uppers Saddle River, NJ: Prentice Hall.

Häder, S. and Gabler, S. 2003. Sampling and Estimations. In Crosscultural Survey Methods, edited by J. Harkness, P. P. Mohler and F. J. R. Ven de Vijver. Hoboken, NJ: Wiley.
Hofstede, G. 1986. Cultural differences in teaching and learning. International Journal of Intercultural Relations 10 (3): 301-320.

Hofstede, G. 1993. Cultural Constraints in Management Theory. Academy of Management Executive 7 (1): 81-94.

Hofstede, G. 2006. What did GLOBE really measure? Researchers' Minds versus Respondents' Minds. Journal of International Business Studies 37 (6): 882-896.

House, R. J. 1995. Leadership in the Twenty-First Century: A Speculative Inquiry. In The Changing Nature of Work, edited by A. Howard, 411-450. San Francisco, CA: Jossey-Bass.

House, R. J., Wright, N. S. and Aditya, R. N. 1997. Cross-cultural research on Organizational Leadership: A Critical Review and a Proposed Theory. In New Perspectives in International Industrial Organizational Psychology, edited by P. C. Early, and M. Erez, 535-625. San Francisco, CA: New Lexington.

House, R. J., Hanges, P. J., Javidan, M., Dorfman, P. W. and Gupta, V. 2004. Culture, Leadership, and Organizations:The GLOBE Study of 62 Societies. Thousand Oaks, CA: Sage Publications.

Huber, D. L., Maas, M., McClosekey, J., Goode, C. J. and Watson, C. 2000. Evaluating Nursing Administration Instruments. Journal of Nursing Administration 30 (5): 251-272.

Javidan, M., Dorfman, P. W., Howell, J. P., Hanges, P. J. 2010. Leadership and Cultural Context. In Handbook of Leadership Theory and Practice, edited by N. Nohria, N. and R. Khurana, 335-376. Boston, MA: Harvard University Press.

Kabasakal, H., Dastmalchian, A., Karacy, G. and Bayraktar, S. 2012. Leadership and culture in the MENA region: An analysis of the GLOBE project. Journal of World Business 47 (4): 519-529.

Kolar, T. 2008. Perceived survey quality and respondent participation. Društvena istraživanja 17 (98): 1203-1217.

Kouzes, J. M. and Posner, B. Z. 1987. The Leadership Challenge: How to Get Extraordinary Things Done in Organizations. San Francisco, CA: Jossey-Bass.

Kouzes, J. M. and Posner, B. Z. 1993. Psychometric Properties of the Leadership Practice Inventory. San Francisco, CA: Pfeifer and Company.

Kouzes, J. M. and Posner, B. Z. 2001. Leadership Practices Inventory [LPI]. 2ed. San Francisco, CA: Jossey-Bass/Pfeiffer.

Kovač, J. and Jesenko, M. 2010.) The connection between trust and leadership styles in Slovene organizations. Journal for East European Management Studies 15 (1): 9-33.

Low, S. P. and Shi, Y. 2001. Cultural influences on organizational processes in international projects: two case studies. Work Study 50 (7): 276-285.

Mabey, C. and Morrell, K. 2011. Leadership in crisis:'Events, my dear boy, events'. Leadership 7 (2): 105-117.

McSweeney, B. 2002. Hofstede's model of national cultural differences and their consequences: A triumph of faith - a failure of analysis. Human Relations 55 (1): 89- 118.

Mellahi, K. 2000. The teaching of leadership on UK MBA programmes: A critical analysis from an international perspective. Journal of Management Development 19 (4): 297-308.

Mihelič, K. K. and Lipičnik, B. 2010. Corporate managers and their potential young successors: An examination of their values. Journal for East European Management Studies 15 (4): 288-311. 
Moan, K. and Hetland, H. 2012. Are leadership preferences universally endorsed or culturally contingent? Scandinavian Journal of Organizational Psychology 4 (1): 5-22.

Mühlbacher, J., Nettekoven, M. and Kovač, J. 2011. Competency management in Slovenia: Paradoxes between Development trends and drivers of change. Journal for East European Management Studies 16 (1): 75-90.

Lord, R. G., Mahler, K. J. 1990. Alternative Information-Processing Models and their Implications for Theory, Research, and Practice. The Academy of Management Review 15 (1): 9-28.

Potočan, V., Mulej, M. and Čančer, V. 2008. Influence of values, culture, ethics and norms on economic results: case of Slovenia. Društvena istraživanja 17 (95): 373-395.

Schwartz, S. H. 1999. A Theory of Cultural Values and some Implications for Work. Applied Psychology - An International Review 48 (1): 23-47.

Scherbaum, C. A., Finlinson, S., Barden, K. and Tamanini, K. 2006. Applications of item response theory to measurement issues in leadership research. The Leadership Quarterly 17 (4): 366-386.

Schwartz, S. H. 1999. A Theory of Cultural Values and some Implications for Work. Applied Psychology - An International Review 48 (1): 23-47.

Schwartz, S. H. and Sagie, G. 2000.Value Consensus and Importance: A Cross-National Study. Journal of Cross-Cultural Psychology 31 (4): 465-497.

Steers, R. M., Sanchez-Runde, C. and Nardon, L. 2012. Leadership in a global context: New directions in research and theory development. Journal of World Business 47 (4): 479-482.

Steyrer, J., Hartz, R. and Schiffinger, M. 2006. Leadership in transformation - between local embeddedness and global challenges. Journal for East European Management Studies 11 (2): 113-139.

Šverko, D. 2009, Emocije u kontekstu dimenzija individualizma i kolektivizma. Društvena istraživanja 6 (104): 1089-1105.

Tang, H.-W.V., Yin, M.-S. and Nelson, D. B. 2010. The relationship between emotional intelligence and leadership practices: $A$ cross-cultural study of academic leaders in Taiwan and the USA. Journal of Managerial Psychology 25 (8): 899-926.
Terraciano et al. 2005. National character does not reflect mean personality traits levels in 49 countries. Science 310 (5745): 96-100.

Thompson, B. 1999. Statistical significance tests, effect size reporting and the vain pursuit of pseudo-objectivity. Theory and Psychology 9 (2): 191-196.

Udovič, B. 2011. Slovene commercial diplomacy in the Western Balkans. Communist post-communist studies 44 (4): 357-368.

Udovič, B. and Svetličič, M. 2012. Does the trio matter? : the case of the Slovenian EU Council presidency. Revista românæa de ştiințe politice 12 (2): 4-28.

Van der Vijver, F.J.R. and Leung, K. 1997. Methods and Data Analysis for Cross-Cultural Research. Thousand Oaks, CA: Sage Publications.

Van der Vijver, F. J. R. 2003. Bias and Substantive Analyses. In Crosscultural Survey Methods, edited by J. Harkness, P. P. Mohler, P. P. and F. J. R. Van der Vijver. Hoboken. NJ: Wiley.

Yammarino, F. J., Dionne, S. D., Chun, J. U. and Dansereau, F. 2005. Leadership and levels of analysis: A state-of-the art science review. The Leadership Quarterly 16 (6): 879-919.

Zagoršek, H. 2004. Universality vs. Cultural Contingency of Leadership: A Comparative Study of Leadership in Six Countries, Doctoral dissertation. Ljubljana: University of Ljubljana, Faculty of Economics.

Zagoršek, H., Jaklič, M. and Stough, S. J. 2004. Comparing Leadership Practices Between United States, Nigeria and Slovenia: Does Culture Matter. Cross Cultural Management: An International Journal 11 (2): 16-34.

Zagoršek, H., Dimovski, V. and Škerlavaj, M. 2009. Transactional and transformation leadership impacts on organizational learning. Journal for East European Management Studies 14 (2): 144-165.

Zupančič, R. and Udovič, B. 2011. Lilliputian in a Goliath world: the preventive diplomacy of Slovenia in solving the question of Kosovo's independence. Revista românæa de ştiințe politice 11 (2): 39-80. 